\title{
COVID-19 Case Fatality Ratio of Latino America Countries with Temperate Climate Partially Follows European and Oceania Trends According to Seasonal Change
}

Cesar Ivan Aviles-Gonzales 1(i), Germano Orrù 2(i), Marìa Verónica Brasesco ${ }^{3}$, Ferdinando Romano $^{4(i)}$, Alessandra Scano ${ }^{2}$ (i), Angelo Restivo ${ }^{5}$ (i), Stefano Del Giacco ${ }^{6}$ (i), Simona Deidda ${ }^{5}$ (i),

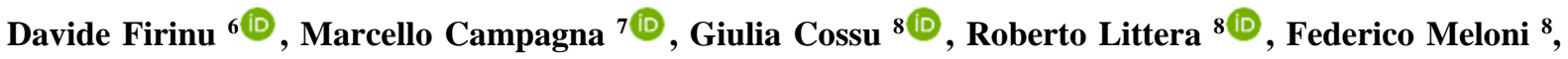
Gabriele Finco $^{8}$ (i), Goce Kalcev ${ }^{9}$ (D), Mauro Giovanni Carta ${ }^{8}$ (D)

1 Cesar University, Colombia; infermiere2010@gmail.com (C.A.G.);

2 Department of Surgical Sciences, University of Cagliari, Italy; gerorru@gmail.com (G.O.), alessandrascano@libero.it (A.S.);

3 Universidas el Salvador, Buenos Aires Argentina; mvbrasesco@gmail.com (M.V,B.);

4 Università di Roma la Sapienza, Rome, Italy; ferdinando.romano@uniroma1.it (F.R.);

5 Colorectal Surgery Unit, Department of Surgical Science, University of Cagliari, Italy; arestivo@unica.it (A.R.), simonadeidda86@gmail.com (S.D.);

6 Internal Medicine, Allergy and Clinical Immunology, Department of Medical Sciences, University of Cagliari, Italy; delgiac@gmail.com (S.D.G), davide.firinu@unica.it (D.F.);

7 Occupational Health Section, Department of Medical Sciences and Public Health, University of Cagliari, Italy; mcampagna@unica.it (M.C.);

8 Department of Medical Sciences and Public Health, University of Cagliari, Italy; giuliaci@icloud.com (G.C.); roby.litter@gmail.com (R.L.); federico.meloni@unica.it (F.M.); gabriele.finco@unica.it (G.F.); mgcarta@tiscali.it (M.G.K.);

9 International PhD in Innovation Sciences and Technologies, University of Cagliari, Italy; gocekalcev@ yahoo.com (G.K.);

* Correspondence: gocekalcev@yahoo.com;

Received: 10.11.2020; Revised: 4.12.2020; Accepted: 6.12.2020; Published: 8.12.2020

\begin{abstract}
The objective of our study is, therefore, to verify whether the trend of the pandemic regarding the lethality of the virus is similar in Argentina and Chile to that which emerged in the temperate countries of Europe and Oceania. The CFRs were derived from the John Hopkins University database. To check the trend of the Case Fatality Ratio and Argentina, Chile we calculated this index on the same dates in which it was calculated for comparison in European countries and in Australia and New Zealand: i.e., May $6^{\text {th }}$ and from May $6^{\text {th }}$ to the September $21^{\text {st }}$. We continued comparing the other countries of the southern hemisphere, recalculating the CFR as of $11^{\text {th }}$ November. For comparing a period of year homogeneous, late spring, we calculate the change if CFR from $20^{\text {th }}$ March to $15^{\text {th }}$ April in the North Hemisphere. Our study's results seem to confirm in Latin America a possible influence of the climate and the changing of the seasons in the lethality of the virus. For the same exceptions, it is evident that the study shows that this factor is not the only one nor probably the most important. The obvious exception concerns Argentina, which does not show any summer improvement of the CFR, unfortunately; for this, nation-specific data are not available to verify if the trend is homogeneous in the different climates that the vast territory presents. Other very important factors come into play, among which the diffusivity of the virus also seems to play a role.
\end{abstract}

Keywords: COVID-19; Latino America; CFR; climate; wheather-linked trends.

(C) 2020 by the authors. This article is an open-access article distributed under the terms and conditions of the Creative Commons Attribution (CC BY) license (https://creativecommons.org/licenses/by/4.0/). 


\section{Introduction}

Previous studies have shown that the lethality of the COVID-19 virus seems to be affected by the climate [1-4]. The COVID-19 shows a worse Case Fatality Ratio (CFR) in European countries with a temperate climate than in countries of the same continent with a colder or warmer Mediterranean climate [5,6]; the lethality of the virus has improved in Europe; with the arrival of summer (measured after lockdown or even in-country as Sweden not adopting lockdown, thus independently of this factor) while in parallel, but with the arrival of winter, it worsened in Australia and remained unchanged in New Zealand [7]; the hot countries of the equatorial belt had a much lower case fatality ratio on average than other countries in the world, with the exception of Ecuador [8, 9]. However, the strong lethality of the virus shown in Ecuador did not change the equator's generally low average when included in the calculation. The data is, however, suggestive of the fact that other environmental factors, besides the heat, play an important role, as on the other hand can be understood and suggested by many sources of literature as the respect of social distances $[10,11]$ or exposure to air pollution and specifically nitrogen dioxide $\left(\mathrm{NO}_{2}\right)$ [12] or to specific [13]. Of course, in addition to factors inherent to the efficiency of health systems in identifying infected people and treating symptomatic people and in the strategy of organizing care $[14,15]$. The exception that occurred in a country of Latin America tends to be interesting to check if trends manifested in Europe and Oceania could be confirmed in countries with a large population in temperate areas in Latino America as Chile and Argentina. Of particular interest is Chile, common with Argentina, it has some climatic areas a variety of different climates that based on different temperatures and rainfall regimes have been classified into four bioclimatic macro-regions: Tropical, Mediterranean, Temperate, and Boreal [16], the last three of which comparable to European macro area climates, and the first three to Australian ones. Argentina, commonly with Chile, has the most densely populated areas with temperate climates [17]. Therefore, our study's objective is to verify whether the trend of the pandemic regarding the lethality of the virus is similar in Argentina and Chile to that which emerged in the temperate countries of Europe and Oceania and to conduct an in-depth analysis in the different areas of Chile.

\section{Materials and Methods}

The CFRs were derived from the John Hopkins University database [18]. To check the trend of the Case Fatality Ratio and Argentina, Chile we calculated this index on the same dates in which it was calculated for comparison in European countries and Australia and New Zealand [7]: i.e., at May $5^{\text {th }}$ and from May $6^{\text {th }}$ to the September $21^{\text {st }}$ (late summer in Europe, late winter in the southern hemisphere). Therefore, we continued comparing the other countries of the southern hemisphere, recalculating the CFR from September $21^{\text {st }}$ to $11^{\text {st }}$ November 2020 for analyzing the post-winter trend. For comparing a period of year homogeneous, late spring, we calculate the change if CFR from $21^{\text {st }}$ March to $15^{\text {th }}$ April in the North Hemisphere.

\section{Results and Discussion}

Table 1 shows the trend of the COVID-19 Case Fatality Ratio in countries having most populated areas with a temperate climate in Latin America in comparison with European and Oceania ones (already published data) at $6^{\text {th }}$ May, (pivot date chosen in previous publications because at the end of the lockdown in the main European countries) vs $21^{\text {st }}$ September 2020 (end of summer in the northern hemisphere and winter in the southern hemisphere). Chile 
presents a consistent trend with the European nations that in winter had presented a high CRF which decreases in spring and summer (from $6^{\text {th }}$ May to $21^{\text {st }}$ September), and Australia, in the same southern hemisphere, which saw the CRF grow in autumn-winter. The figure is hardly comparable with New Zealand; in this country, the CRF remains stable in the analyzed period because the epidemic had already practically stopped. The trend is not confirmed in Argentina, where on the contrary, the CFR decreases in the winter.

Table 2 shows the trend of COVID-19 Case Fatality Ratio in Australian and Boreal Hemisphere from the end of the winter and late spring (21/9 to 15/11) and a comparable period in the Boreal Hemisphere (from 20/3 to 15/4). Although in two different phases of the pandemic, Chile and Argentina show the same trend as the European nations at the beginning of spring. In New Zealand and Australia, there is an opposite trend. In both countries, the pandemic is almost over or silent. The greatest increase in Europe is seen in Belgium, the UK, and Sweden. When analyzing the trend over the same period in the specific areas of Chile, it is noted that CFR tends to decrease in all five Oceanic and Subpolar areas (OS), while in all other areas (the Mediterranean, Dry and Tropical areas) tends to tend to increase (100\% vs. $9.1 \%$ of areas with Fisher test $\mathrm{p}=0.001$ improvements).

Table 1. Trend of the Covid-19 Case Fatality Ratio in Temperate Countries (6 $6^{\text {th }}$ May vs. $21^{\text {st }}$ September 2020 comparison of South America Countries with already published data).

\begin{tabular}{l|l|l|l|l|l} 
& $\begin{array}{l}\text { CFR \% } \\
\text { To 5 }\end{array}$ & $\begin{array}{l}\text { CFR\% } \\
\mathbf{2 1}^{\text {st }} \text { September }\end{array}$ & $\begin{array}{l}\text { Chi } \\
\text { square }\end{array}$ & $\mathbf{p}$ & OR(CI 95\%) \\
\hline Italy & $13.8 \%$ & 6.9 & 2844.6 & $<0.00001$ & $2.1(2.0-2.2)$ \\
\hline France & $14.8 \%$ & $1.6 \%$ & 35409.2 & $<0.00001$ & $10.1(10.4-10.7)$ \\
\hline Belgium & $16.4 \%$ & $2.9 \%$ & 5778.7 & $<0.00001$ & $6.6(6.2-7.0)$ \\
\hline Germany & $4.3 \%$ & $1.9 \%$ & 1154.6 & $<0.00001$ & $2.3(2.2-2.4)$ \\
\hline The Netherlands & $11.0 \%$ & $1.9 \%$ & 21646.3 & $<0.00001$ & $40(37-43)$ \\
\hline Spain & $11.7 \%$ & $1.1 \%$ & 40644.9 & $<0.00001$ & $12.1(11.7-12.5)$ \\
\hline UK & $14.9 \%$ & $5.7 \%$ & 9634.9 & $<0.00001$ & $2.9(2.8-3.0)$ \\
\hline Sweden & $13.9 \%$ & $3.7 \%$ & 3014.0 & $<0.00001$ & $4.1(3.9-4.3)$ \\
\hline Australia & $1.4 \%$ & $3.8 \%$ & 95.4 & $<0.00001$ & $0.4(0.3-0.5)$ \\
\hline New Zealand & 1.4 & 1.3 & $0.05 *$ & 0.995 & $1.2(3.4-3.5)$ \\
\hline Chile & 1.2 & 2.7 & 210.435 & $\mathrm{p}<0.0001$ & $0.4(0.4-0.5)$ \\
\hline Argentina & $5.3 \%$ & $2.1 \%$ & 216.8 & $\mathrm{p}<0.0001$ & $2.5(2.2-2.8)$
\end{tabular}

Table 2. Trend of Covid- 19 Case Fatality Ratio post winter in Australian hemisphere (6/5 to 21/9) against a similar period of a year in Boreal hemisphere (15/3-1/4).

\begin{tabular}{|c|c|c|c|c|}
\hline & $\begin{array}{c}\text { CFR \% } \\
6 / 5 \text { to } 21 / 9 \text { (South) } \\
\text { At } 21 / 3 \text { (North) } \\
\end{array}$ & $\begin{array}{c}\text { CFR\% } \\
22 / 9 \text { to } 15 / 11 \text { (South) } \\
22 / 3 \text { to } 15 / 4 \text { (North) } \\
\end{array}$ & Chi square & $\mathbf{p}$ \\
\hline Australia & 3.8 & 0.4 & 166.44 & $<0.00001$ \\
\hline New Zealand & 1.3 & $\mathrm{o}$ & 2.076 & 0.150 \\
\hline Chile & 2.7 & 3.1 & 217.6 & $<0.00001$ \\
\hline Argentina & 2.1 & 3.4 & 1851.2 & $<0.00001$ \\
\hline Italy & 6.4 & 16.3 & 1209.9 & $<0.00001$ \\
\hline France & 2.0 & 13.4 & 422.9 & $<0.00001$ \\
\hline Belgium & 0.4 & 17.0 & 141.5 & $<0.00001$ \\
\hline Germany & 0.2 & 3.4 & 172.3 & $<0.00001$ \\
\hline TheNetherlands & 1.8 & 12.3 & 206.3 & $<0.00001$ \\
\hline Spain & 3.7 & 15.9 & 867.6 & $<0.00001$ \\
\hline UK & 1.5 & 17.5 & 457.4 & $<0.00001$ \\
\hline Sweden & 0.1 & 16.3 & 76.4 & $<0.00001$ \\
\hline
\end{tabular}

\subsection{Discussion.}

The study shows that the COVID-19 Case Fatality Ratio of Latino American Countries with main areas with a temperate climate (i.e., Chile and Argentina) partially follows European and Oceania weather-linked trends already published [5,7]. In Chile, in CFR it worsens in 
winter as in New Zealand and Australia. At the same time, there is no similar comparison with Europe that was hit by the pandemic at the end of last winter. During the present observation, it was at the gates of winter 2020/2021. However, Argentina shows the opposite trend. However, let's consider the first part of spring. A similar trend is shown in Chile and Argentina compared to Europe. The trend is not conformed in Australia and Oceania. However, in these countries, in the period under review, there are practically no new cases, so the comparison is not feasible. On the other hand, if it is true that in New Zealand in the period under consideration, no cases were detected [19], therefore the CRF cannot be considered and compared; in Australia, a prolonged lockdown has led to the emergence of very few cases, and almost none died, but with a CFR very low. On the opposite, it should be noted that the European nations that did not have a lockdown in place at the time, i.e., Belgium (which started it on March 18 ${ }^{\text {th }}$ ) [20], UK [21], and Sweden [22], are those with the strongest increase in the CFR. All these considerations suggest that even the density of the spread of the virus may, in an unknown way, worsen CFR. As far as very high increases are concerned, an effect on the health network's efficiency can be thought of. However, this explanation is not plausible when applied to changes in already low frequencies (i.e., in Australia and New Zealand at the beginning of the observation). The Covid incidence rate was already rallied low. On the other hand, between $15^{\text {th }}$ March and $15^{\text {th }}$ April, the European countries with the greater CFR change were not yet in crisis with their robust health systems as they would be a few weeks later. The study, therefore, suggests that an unknown factor intrinsically linked to the high incidence of infection may be causing an increase in CFR.

On the other hand, although our study results seem to confirm in Latin America a possible influence of the climate and the changing seasons in the lethality of the virus. For the same exceptions, it is evident that the study shows that this factor is not the only one nor probably the most important. The obvious exception concerns Argentina, which does not show any summer improvement of the CFR. Unfortunately, nation-specific data cannot verify if the trend is homogeneous in the different climates that the vast territory presents. Climate change is an important element that must be considered in that indispensable strategy that must be implemented in the organization of resources to counter the pandemic $[3,6,23,24]$.

\section{Conclusions}

The study confirms that even in Latin America, the climate can affect the lethality of Covid 19. During the winter, the CFR trend is similar in Chile to Australia (Europe has not yet gone through winter during the pandemic). Both Chile and Argentina show in the first part of spring a worsening trend of the CFR in homogeneity with Europe, albeit in very different phases of the pandemic (in this case, the comparison, not Oceania is not feasible because in the two oceanic countries with feared areas the epidemic is now silent). However, other significant factors come into play. The diffusivity of the virus also seems to play a role.

\section{Funding}

This research received no external funding.

\section{Acknowledgments}

Goce Kalcev (M.D.) participated in writing this paper in the framework of the International Ph.D. in Innovation Sciences and Technologies at the University of Cagliari, Italy. 


\section{Conflicts of Interest}

\section{The authors declare no conflict of interest.}

\section{References}

1. Lin, S.; Fu, Y.; Jia, X.; Ding, S.; Wu, Y.; Huang, Z. Discovering Correlations between the COVID-19 Epidemic Spread and Climate. International Journal of Environmental Research and Public Health 2020, 17, https://doi.org/10.3390/ijerph17217958.

2. Cacho, P.M.; Hernández, J.L.; López-Hoyos, M.; Martínez-Taboada, V.M. Can climatic factors explain the differences in COVID-19 incidence and severity across the Spanish regions?: An ecological study. Environmental Health 2020, 19, https://doi.org/10.1186/s12940-020-00660-4.

3. Carta, M.G.; Orrù, G.; Scano, A.; Coghe, F.; Nunnari, G.; Facchini, G.; Numis, F.G.; Berretta, M. In the face of the SARS-CoV-2 outbreak, do people suffering from oncological disease need specific attention? Eur Rev Med Pharmacol Sci 2020, 24, 3434-3436, https://doi.org/10.26355/eurrev_202004_20794.

4. Zaitchik, B.F.; Sweijd, N.; Shumake-Guillemot, J.; Morse, A.; Gordon, C.; Marty, A.; Trtanj, J.; Luterbacher, J.; Botai, J.; Behera, S.; Lu, Y.; Olwoch, J.; Takahashi, K.; Stowell, J.D.; Rodó, X. A framework for research linking weather, climate and COVID-19. Nature Communications 2020, 11, https://doi.org/10.1038/s41467020-19546-7.

5. Orrù, G, Romano, F.; Scano, A.; Restivo, A.; Del Giacco, S.; Deidda, S.; Firinu, D.; Campagna, M.; Cossu, G.; Kalcev, G.; Carta, M.G. Climate in the European Union and the enlarged European regionis a determinant of COVID-19 Case Fatality Ratio. Biointerface Research in Applied Chemistry 2021, 11,10979-10986.

6. Carta, M.G.; Romano, F.; Orrù, G. The True Challenges of the Covid-19 Epidemics: The Need for Essential Levels of Care for All. Open Respir Med J 2020, 14, 8-9, https://doi.org/10.2174/1874306402014010008.

7. Carta, M.G.; Kalcev, G.; Scano, A.; Romano, F.; Cossu, G.; Littera, R.; Perra, A.; Deidda, S.; Firinu, D.; Del Giacco, S.; Campagna, M.; Chessa, L.; Zorcolo, L.; Restivo, A.; Orrù, G. Is the inversion in the trend of the Lethality of the COVID-19 in the two hemispheres due to the difference in seasons and weather? Biointerface Research in Applied Chemistry 2021, 11, 10429-10434.

8. Carta, M.G.; Scano, A.; Lindert, J.; Bonanno, S.; Rinaldi, L.; Fais, S.; Orrù, G. Association between the spread of COVID-19 and weather-climatic parameters. Eur Rev Med Pharmacol Sci 2020, 24, 8226-8231, https://doi.org/10.26355/eurrev_202008_22512.

9. Carta, M.G.; Scano, A.; Minerba, L.; Romano, F.; Orrù, G. Does living in previously exposed malaria or warm areas is associated with a lower risk of severe COVID-19 infection in Italy? Biointerface Research in Applied Chemistry 2021, 11, 9744-9748, https://doi.org/10.33263/BRIAC112.97449748.

10. Wang, Z.; Fu, Y.; Guo, Z.; Li, J.; Li, J.; Cheng, H.; Lu, B.; Sun, Q. Transmission and prevention of SARSCoV-2. Biochemical Society transactions 2020, 48, 2307-2316, https://doi.org/10.1042/BST20200693.

11. Bugalia, S.; Bajiya, VP.; Tripathi, J.P.; Li, M.T.; Sun, G.Q. Mathematical modeling of COVID-19 transmission: the roles of intervention strategies and lockdown. Math Biosci Eng 2020, 17, 5961-5986, https://doi.org/10.3934/mbe.2020318.

12. Huang, G.; Brown, P.E. Population-weighted exposure to air pollution and COVID-19 incidence in Germany. Spatial statistics 2021, 41, https://doi.org/10.1016/j.spasta.2020.100480.

13. Carta, M.G.; Preti, A.; Akiskal, H.S. Coping with the New Era: Noise and Light Pollution, Hperactivity and Steroid Hormones. Towards an Evolutionary View of Bipolar Disorders. Clinical Practice \& Epidemiology in Mental Health, 2018, 14, 33-36, https://doi.org/10.2174/1745017901814010033.

14. Kuniya, T.; Inaba, H. Possible effects of mixed prevention strategy for COVID-19 epidemic: massive testing, quarantine and social distancing. AIMS Public Health 2020, 7, 490-503, https://doi.org/10.3934/publichealth.2020040.

15. Kalcev, G.; Preti, A.; Orrù, G.; Carta, M.G. Mental Health and the COVID-19 Pandemic: A Call for Action. The Open Public Health Journal 2020, 13, 411-412, https://doi.org/10.2174/1874944502013010411.

16. Amigo, J.; Ramírez, C. A bioclimatic classification of Chile: woodland communities in the temperate zone. Plant ecology 1998, 136, 9-26, https://doi.org/10.1023/A:1009714201917,

17. Olascoaga, M.J. Some Aspects of Argentine Rainfall. Tellus 1950, 2, 312-318.

18. John Hopkins University, Coronavirus Resource Center 2020. Available at: https://coronavirus.jhu.edu/, retrieved, 2020.

19. Gray, B. COVID-19 from Wellington New Zealand. J Bioeth Inq 2020, 9, 1-6, https://doi.org/10.1007/s11673-020-10038-3.

20. He, R.; Zhang, J.; Mao, Y.; Degomme, O.; Zhang, W.H. Preparedness and Responses Faced during the COVID-19 Pandemic in Belgium: An Observational Study and Using the National Open Data. International journal of environmental research and public health 2020, 17, https://doi.org/10.3390/ijerph17217985,

21. Bhanot, G.; DeLisi, C. Analysis of Covid-19 Data for Eight European Countries and the United Kingdom Using a Simplified SIR Model. Research square 2020, https://doi.org/10.21203/rs.3.rs-97697/v1.

22. Helsingen, L.M.; Refsum, E.; Gjøstein, D.K.; Løberg, M.; Bretthauer, M.; Kalager, M.; Emilsson, L.; for the Clinical Effectiveness Research, g. The COVID-19 pandemic in Norway and Sweden - threats, trust, and 
impact on daily life: a comparative survey. BMC Public Health 2020, 20, https://doi.org/10.1186/s12889020-09615-3.

23. Petretto, D.R.; Masala, I.; Masala, C. School Closure and Children in the Outbreak of COVID-19. Clinical Practice \& Epidemiology in Mental Health 2020, 16, 189-191, https://doi.org/10.2174/1745017902016010189,

24. Virtual Symposium on Climatological, Meteorological and Environmental (CME). Outcome Statement. Factors in the COVID-19 Pandemic.v2020, https://public.wmo.int/en/events/meetings/covid19-symposium/outcomes. 